\title{
Business Partnerships in Local Government
}

\author{
Eti Sarig \\ The Open University, Raanana, Israel \\ Email: etisa@openu.ac.il
}

Received 18 June 2015; accepted 29 August 2015; published 1 September 2015

Copyright (C) 2015 by author and Scientific Research Publishing Inc.

This work is licensed under the Creative Commons Attribution International License (CC BY). http://creativecommons.org/licenses/by/4.0/

(c) (i) Open Access

\begin{abstract}
This study tests the predictive ability of a number of factors that affect local municipal business partnerships, including development policy, municipality size, geographical location, national priority and the characteristics of the municipality and its leader. Using original survey data and a variety of data sources, the research model tests the influence of these institutional, individual and environmental factors on the scope of municipal business partnerships. The paper suggests that political factors are still dominant in local decision making processes and finds a dramatic rise in business partnerships and mixed public-private delivery (joint contracting) of city services.
\end{abstract}

\section{Keywords}

Partnership, Local Government, Local Municipality, Business Partnerships, Private Sector, Voluntary Sector, Non-Profit Organizations

\section{Introduction}

The partnership among the local municipality, the business sector and non-profit organizations was first conceived as the result of financial difficulties of local municipalities. In an attempt to cope with this difficulty, local municipalities realized that economic development could provide them with alternative sources of funds, one of which was the widening the municipal tax base. The business sector could contribute to the achievement of this goal by investing in regions under the municipality's jurisdiction, creating sources of employment in these areas, and in general stimulating the growth of economic activity.

Simultaneously, increasingly negative views regarding the far-reaching intervention of the local municipality in business aspects of municipal management and the advent of new managerial values emphasized the need for flexibility in municipal activities, and for new thinking regarding alternative methods for service delivery, thus accelerating the partnership between local municipalities and the business sector. This development, although not without risks, enables the local municipality, using local enterprise, to improve the quality of service delivered to its citizens, increasing their welfare and consequently enhancing the city's attractiveness. 
The emergence of "New Public Management" (NPM) and its faith in markets led governments to search for alternative methods for public services delivery. One of the most popular methods was privatization. The rationale behind the choice of privatization is based on the assumption of "non-market failure". But, there are situations in which the market may not be as efficient. For example, when there is a monopoly over service delivery, as is the case in water and sewage services in many local municipalities in Israel as well as in the City of Hamilton's experience (Ohemeng \& Grant, 2008). Or when there is limited potential for redistribution in rural municipalities with small number of services provided, or when sparsity may make such services less attractive to market suppliers (Warner, 2006). Furthermore, privatization may have negative social influences, such as unemployment and uncertainty of cost savings (Lamothe, Lamothe, \& Feiock, 2008), the uncertainty of outcomes and its impact on the short-term and long-term quality and cost of the public service to consumer (Hurte, 2004). Factors like these arouse protest (Kidd, 2002) and the negative connotation of privatization. Therefore, although national policy in Israel continues to advance a privatization agenda, policy-makers concerned about the uneven impacts of such market-based approaches are inclined to prefer partnership to privatization.

Empirical studies of local government contracting for services have suggested that the political factors still matter when it comes to explaining patterns in local governments' adoption of alternative services delivery (Warner \& Bel, 2008). Public service delivery and management in local government in Europe show two major approaches to reforms: privatization, contracting-out, and "corporatization" of local services on one hand, and public management reforms on the other (Kuhlmann, 2008). The direction of the course of privatization in local municipalities in the US shows declining use of complete contracts and a dramatic rise in mixed public-private delivery (joint contracting) of city services (Warner \& Hefetz, 2008). One of the main reasons is the need to balance economic concerns with the political engagement of the citizens (Hefetz \& Warner, 2007; Warner, 2009).

The present study aims to clarify and explain one of the key areas of NPM, which is becoming increasingly prevalent in local municipalities in Israel. For this purpose, it examines the different types of business partnerships most commonly found among local municipalities, the business sector and voluntary organizations, while focusing on the components that are essential for the creation of a development policy whose aim is to encourage business partnerships with the business sector for urban development. This study will attempt to respond to the following questions. How many local municipalities use development policy in order to attract local enterprises? Which of the incentives offered most influence the investment of private capital in local municipalities? What different types of partnerships between local municipalities and the private and voluntary sector are commonly used by local municipalities in Israel? The data obtained will enable classification of the types of partnerships that exist in the local municipalities according to variables such as municipality size, geographical location and national priority.

\subsection{Urban Business Partnerships}

Urban business partnerships are created, following elections, between local municipalities and business elites from different sectors. They are characterized by entrepreneurial activity that focuses on the development of industrial parks, public infrastructure, transport, cultural and educational centers, etc. Within the partnership, the local municipality creates a policy of joint economic development, using both private and public capital, which provides concessions and incentives for businessmen, with the aim of encouraging investment in the development of the municipal infrastructure and facilities (Reese \& Rosenfeld, 2002).

Partnership with the private sector enables the local municipality to enjoy the advantages of flexibility due to the independence of private bodies, and to develop variety and innovation in the services it offers. For example, research conducted in Canada on education (Hanley, 2003) found that the reason for partnerships with the private sector was the expectation of revitalising education and raising the level and quality of education services. It was anticipated that cooperation with artists would introduce excitement and innovation into the education system, and increase the satisfaction of pupils and parents, resulting in an increase in the level of pupils' achievements.

An additional advantage of partnership is saving money, due to management methods used in the business sector and because of the reduction in manpower costs, which are usually lower in the private sector than in the public sector, although these savings may impair the municipal services by reducing their scope and quality. This may have social consequences and therefore cause damage in the long-term as well as in the short-term. It is important to examine whether such partnerships, which stem from economic motives on both sides, harm es- 
sential public services. An additional aspect that needs to be considered is whether partnership with the business sector for the delivery of essential services obligates the business sector to solve problems in the area of municipal services, while the municipality's involvement is only symbolic (Silver, 2001).

\subsection{Partnership with the Private Sector}

In the 1980s, the aim of partnerships was raising capital only, but in time, the municipality became an active and involved partner. The partnership was based not only on public principles such as raising the quality of life and developing the economy in order to produce a profit with the private sector and other partners outside of the local municipality. Local governments used private and public sector mechanisms to structure the market, create competition and attain economies of scale (Warner \& Hebdon, 2001).

Frisby, Thibault, \& Kikulis (2004) focus on municipal structure and management processes such as planning, definition of goals and manpower skills. Local governments had to carry out structural changes as a result of the rise in service demands, while retaining the level of taxation and its volume, using public funds efficiently, transferring responsibilities of the central government to the local government, and reducing manpower all within the budget. All these factors led the local government to enter into partnerships with the private sector that made it possible to supply high-quality services but which necessitated structural strategic changes in administrative units so they could cope with an increased number of partners.

DiGaetano \& Strom (2003) explain the variance in partnerships by the environment of the local institutions. Other schools of thought explain the differences by varied structural connections, urban policy and rational actors. Dowding (2001), de Socio (2007), Stone (1980), Elkin (1987) and others in the US explain difference by factors such as the character of land ownership and use, the taxation system, and distribution of revenues. According to Stone (2005), a suitable climate for business investment and a developing economy create an advantage in determining the agenda of large American cities and the partnerships with the organized business sector make them very important partners in the local government economy and part of the local government texture. Reese \& Rosenfeld (2002) indicate that partnerships varied in the local culture differences: "Local governments may be similar in all unimportant respects: for example, form of government, tax base and even governing coalition. It is the fine distinctions in local culture, the habits of how interests are balanced, problems defined, symbols interpreted, goals envisioned, and decisions made that will have the greatest and perhaps most subtle effects on public policy" (p. 665). This may explain the fact that Hebdon \& Jalette (2008) found in their research that the Canadian municipalities offered more services through the private sector than their American counterparts.

\subsection{Partnerships with Voluntary Organizations}

In many Europe countries, as well as in Israel, the central government's policy is to encourage partnerships with voluntary organizations. The aim of this policy is to create a more efficient, flexible and modern system, with the local government providing fewer services and dealing more with monitoring contractors and determining how to deliver the services. This is based on the assumption that in a free economy market, the market forces will force the public organizations (among them the municipalities) to be more efficient, save public funds and use management methods with an economic orientation. The focus of the partnerships between the municipalities and the voluntary organizations are in the social area and welfare services delivery. These partnerships are based on mutual interests, but the government determines who is entitled to the services, plans the basket of services, chooses the service providers, and monitors their activities, while the organizations from the voluntary sector deliver the services under public instruction and public finance. In this way, the voluntary sector fills the role of the local authority and sometimes even replaces it. The local government retains its focus on the arrangement and finance of the services. The voluntary organizations are not profit motivated (Katan, 2001) but choose to work with the municipalities because they seek to develop and extend their activity to new areas.

The local municipalities take advantage of the special attribute of the voluntary organization including their volunteer staff and various sources of income, from donations and grants. These advantages enable the municipalities to increase their activities without increasing their expenses. The uniqueness of these partnerships is based on full partnership of the two sectors (public-private) in the sense of sharing the responsibility, the authority and the risks in all stages of planning, financing, establishing and operating. In recent years, there is increased recognition that the economic and social development of the community and of the region depends on more than only economic factors. In additional to fiscal and human capital, there is another important resource: 
"social capital," resulting from the close relationships, cooperation and readiness for personal involvement between citizens that may make it easier to develop community benefits. For example, Lev-Ari \& Pavin (2006) examined cooperation between communities in the Beit Shean valley in Israel and found a considerable stock of regional "social capital" that could encourage the development of infrastructure in the area. This social capital is "a resource in waiting" and can be utilized only if an entity is found to activate it.

\subsection{Advantages, Disadvantages and Risks in Partnerships}

Among the advantages of partnerships, we find that the diversity of organizations supplying services and the competition between them improves the service delivery as long as the competition is not aggressive (Katan, 2004). Operating in the market under competitive conditions motivates the organizations to offer high quality goods and services to the consumers at an appropriate price (Katan, 2001) and consumers can choose or replace suppliers that do not satisfy them. The efficiency and flexibility of the business sector allows it to deliver services at lower cost by lowering the number of local municipality employees (Kop, 2004). At the same time, it has become possible to enlist additional local resources from non-governmental sources. The importance of these partnerships increases in a period when there are reduced sources of funds available to local municipalities. However, there are quite a few disadvantages as well. These include the possible conflict between concern for the welfare of the population and the aspiration to produce profits, which is the main motivation of business bodies, and is especially pertinent with regard to weak and vulnerable population groups. Another (not less important) point is that the multiplicity of non-governmental groups delivering services makes it difficult for many citizens to choose a service supplier. In many cases, citizens do not have a real right of choice, since they do not possess sufficient information regarding the service suppliers. Thus, without government involvement in the form of supervision and guidance, damage can be caused in particular to weaker populations, who, owing to lack of education and experience, have difficulty in collecting sufficient information or analyzing it properly, in order to make an informed choice about who will best answer their needs and meet their expectations.

The private sector has no social orientation and no interest in achieving social objectives, such as ensuring a supply of high quality services for socially marginal groups. There is an expectation that the government will make sure that all citizens receive the minimal service "basket" to which they are entitled, irrespective of income, domicile and the like, and for this purpose the government is expected to operate effective mechanisms for funding and inspection. There is doubt about the ability of local municipalities to guide and direct the activities of service suppliers. Moreover, the transfer of service delivery to the private and voluntary sector causes changes in the character of many local municipality departments, and in the functions of their employees. Their professional contact with residents receiving the services is reduced, and direct contact with individuals and families who, in the past, were in their care, is severed. They thus focus more on managerial, bureaucratic activity (such as examination of reports and conducting negotiations), that involves coordination with service suppliers and supervision of their activities - tasks for which they have not been trained. Finally, the dependence on government funding of non-governmental (private and voluntary) organizations supplying social services may harm the character, functioning and even the independence of these organizations, because of the need to respond to the demands of the directive and supervisory policies of the government. These demands reinforce the bureaucratic components of the organization's activities (Katan, 2004).

One of the arguments against municipal partnerships is the unequal distribution of resources because of the profit-seeking nature of the business sector (Lake, 2002). In order to create partnerships with the business sector that develop the city's economy and structure, most of the municipalities formulated a development policy, which includes the provision of incentives such as tax concessions, financial incentives, and so forth. Arguments are also raised against partnerships with voluntary organizations (community centers, private funds and religion institutions). As non-profit organizations, there are cases when, due to lack of financing, shortage of staff, problems of administrative qualifications, political ineffectiveness, etc., their dependence on financing and political support limits their ability to provide the social services, medical care, professional training and other services. In such cases, stresses arise between the organization's aim to provide services and their attempt to ensure their continued functioning, in competition with organizations under their control and with organizations that compete with them in the private sector. All these factors lead to seeking short-term solutions. Therefore, not only do they not solving their problems, they aggravate them (Lake, 2002).

The risks involved in municipality partnerships can be divided into three areas: economic, social and political. 
In the economic area, there is risk that assets and resources may be lost because of lack of skill and experience in this area. In the social area, preference may be given to economic development at the expense of social and environmental development. An additional risk is the subordination of business considerations to political considerations, which may lead to lack of effectiveness, and even to corruption. In the political area, a new model of local democracy may be created, in which the principle of representation is exchanged for the principle of participation, so that representative democracy is eroded and authority and influence are transferred to non-elected bodies. In other words, a participatory democracy will replace the representative democracy.

In summary, research that focuses on the advantages and risks involved in sharing municipal activities with private and voluntary sectors shows the complexity involved in the transfer of public functions to non-governmental bodies (e.g., Katan, 2001, 2004; Schwarz, 2003; Schmid, 2001). Other warnings concern the attrition of the commitment of state and local government to protect their citizens' basic social rights, the damage to consumers with limited means, the creation of gaps between the services delivered to different populations, the intrusion of profit-making motives into welfare services, the erosion of public supervision of service provision, and the substantive alteration in the character and functioning of both the municipal departments and the business organization.

In contrast, other research, although not ignoring the risk of damage to the public interest and the achievement of social objectives, indicates that the involvement of NGOs not only does not harm the public interest, but, in some cases, even contributes to it (Katan, 2004). As an example, they cite the entry of many private and voluntary bodies and informal aid networks into the welfare field. To a considerable extent, they claim, this compensates for the damage caused by cutbacks in government and local municipality spending, helping to fill the gaps in the services system caused by the cuts, and even enabling expansion of different services intended for weak populations, such as food distribution centers and aid for families in distress.

The positive and negative implications of the partnership contribute to the dilemmas with which central and local government must cope. Those who do not support business partnership caution against the social and economic dangers involved. Nevertheless, they are aware that even without such partnership, the economic environment in which government bodies operate will force them to act more effectively, and to be transparent to the public, increasing their accountability in order to face the non-governmental organizations competing to supply services and local business activity. Indeed, changes that have occurred in recent years have already forced the local municipalities to make structural-organizational changes in order to be able to continue to achieve their goals.

Those who support cooperation and partnership with private and voluntary sectors in public activities rely on the assumption, prevalent in the free economic market, that market forces compel public organizations, including the local municipalities, to act more efficiently, saving public funds and introducing managerial methods with an economic orientation. Thus, in their opinion, partnership should be encouraged, and certainly in the face of the financial constraints with which most of the local municipalities are coping. Given these dilemmas, the declared policy of the government in Israel is to encourage such partnership. In part, the government policy is similar to that of many European countries, intending to create a more flexible, effective and modern system, in which the local municipality would deal less with the direct delivery of services, and more with steering and supervising the services delivered by sub-contractors and by the private and voluntary sector.

\subsection{Business Partnerships: The Case Study}

Partnerships between local municipalities and the private and voluntary sectors are not a new phenomenon in Israel. The involvement of NGOs has deep historical roots that date back to the period before the establishment of the state. In recent years, the partnership has also spread into areas that were traditionally the exclusive responsibility of the local municipality. The reasons for this are both global-the accumulation of flexible capital, the transition from industrial to post-industrial economies, and ideological and political changes (Hasson \& Hazan, 1997) - and local — the withdrawal of the central government from its historical commitments and the reduction of resources from this source, the demand for high quality services, local municipalities' chronic deficits and the desire to increase efficiency, as well as increasing public recognition of the virtues of the private and voluntary sectors as service suppliers.

Nevertheless, the partnership between local municipalities and the private sector in Israel is characterized by the lack of a comprehensive and uniform policy. Implementation is, in practice, based on various factors, prin- 
cipally in areas of economic activity stemming both from the desire of the local municipalities to stimulate local economic growth, and from the business sector's aspiration to maximize profits. The partnership takes different forms according to the character of the city (size, socio-economic status, location, etc.) and, in particular, according to the characteristics of the head of the local municipality (coalition status, charisma, policies and vision regarding the development of the city).

\subsection{How the Partnership Works-A General Model}

One of the most common ways to create a business partnership is to establish a municipal company, whose function is to engage in the economic development of the local municipality. This municipal company searches for an entrepreneur from the business sector and creates a partnership in order to implement a project, which, due to legal restrictions and because of the economic orientation of the partnership, cannot be accomplished as part of a direct partnership between the local municipality itself and the private sector. The partnership, established through the municipal company, is dependent upon approval by the Ministry of the Interior. It is important to note that this is a general and simplified model, and that these municipal partnerships are not uniform. They vary according to the economic situation of the local municipality (real estate, infrastructure, ease of access to sources of funding), the demands and requirements of the citizens, and the specific characteristics of the partner.

\section{Methodology}

The empirical study reported here was carried out in two stages. The first stage was a pilot study based on a series of interviews with the heads of local municipalities, who decide on the development policy of the municipality. Based on the data obtained, a self-report questionnaire was constructed and sent to all local municipalities in Israel. The second stage was analysis of the data obtained from those local municipalities that completed the questionnaire. This provided qualitative data on independent variables including development policy and characteristics of the head of the municipality, as well as on the dependent variable: the scope of partnership (SOP) in the municipality. Most of this data cannot be obtained from on-line sources. In addition, to avoid common method error (Carmeli, 2000), quantitative data was obtained from various online sources, and used to examine the following variables: municipal population characteristics, municipal size, geographic location and national priority. This data provided the basis for developing objective indexes to enable comparative research on local municipalities in Israel (to date, performed only by Hasson \& Hazan, 1997).

The study population included 252 local municipalities ( 76 cities or towns, 123 local councils and 53 regional councils). Of the 67 questionnaires returned, representing $26.5 \%$ of all local municipalities, 61 questionnaires were used in the analysis ( 6 questionnaires were incomplete or invalid). This low response rate can be explained by the sensitive nature of the topic, lack of interest and of the participant's time, and represents a research limitation. Another limitation is that only one questionnaire was administered in each municipality, whereas using three different questionnaires would have been preferable.

Correlations between the research variables were analyzed using a series of OLS regressions. Direct relationships between the independent variables and the dependent variable (SOP) were analyzed, as was the contribution of each independent variable to explaining variance in SOP. The data were analyzed using SPSS for Windows (version 7). The study was conducted at a statistical significance level of 0.05 , an accepted significance level in social science research.

\subsection{The Research Variables and Analysis}

The research model is based on Stone (2005), who presents the components essential for the creation of a stable coalition in an American city, and on research by Hasson \& Hazan (1997) — the only study so far conducted on this subject in local municipalities in Israel. The model includes a group of independent variables: municipality head characteristics, municipality population characteristics (economic status and social level), geographical location, national priority, municipality size, and development policy. The dependent variable was the scope of partnerships (SOP) between the local municipality and the private or the voluntary sector.

Municipality head characteristics relate to the political characteristics (political strength and political status) of the head of the local municipality. The assumption is that a strong municipality head (defined as more domi- 
nant in the municipality decision making process or in the implementation of policy compatible with his or her political and economic policy) will have more influence than one defined as weak. The variable is composed of three separate factors: the number of terms served, coalitional stability and the size of the coalition. The variable was coded into two categories: a strong municipality head was defined as one who has served two terms, and heads a large (more than $45 \%$ of the seats) and stable coalition. A weak municipality head was defined as one who served only one term and has a small (less than $44 \%$ of the seats) and unstable coalition.

Municipality population characteristics relates to the economic and social characteristics of the local municipality, which affect the policy regarding the creation of business partnerships. Dye \& Garcia (1978) claim that demographic characteristics such as poor, old, lacking in education and skills, cause changes in the municipality's expense level and tax weight, which effect its policy-making process. Stein (1990) notes that a municipality with a homogenous population that is weak economically and socially has to use alternative service delivery so they can provide services, whereas a municipality with a wealthy population can usually use contracting out to improve the quality and quantity of the services. Ben-Elia (1996) found a similar phenomenon in Israel. Therefore, economic and social characteristics can be used as good indicator to explain the decision to create partnerships with the private and voluntary sectors. The assumption is that in strong municipalities (from an economic and social point of view), the SOP will be higher than in weak municipalities. The social status factor in the variable municipality population characteristics is determined by the Central Bureau of Statistics (CBS) indicator of the socio-economic situation, which includes level of education, source of income, etc. The CBS divided the population characteristics of the municipalities into 10 groups, with 10 indicating a strong municipality on a high socio-economic level. The 10 categories were coded as 0 or 1, with 0 representing categories 1 to 5 (weak municipalities), and 1 representing categories 6 to 10 (strong municipalities).

Geographic location refers to location in the center or periphery of the country. The municipal location influences SOP because of the private sector's interest in a location that is advantageous for its operational and environmental market business target. There are activities that require an urban business environment to ensure convenient distribution of goods; for other activities, a location near a large city is not necessary to achieve business success and sometimes a peripheral location that provides a lot of cheap land is preferable. Geographic location of the municipality is a central factor in any economic decision by the firm. The assumption is that SOP in municipalities located in the center of the country will be larger than in municipalities located in the periphery because of the relatively high number of opportunities for business entrepreneurship, and the existence of large and varied manpower. This is a nominal variable that expresses the municipality's geographic location in the country. The data is taken from the Ministry of the Interior and the measure is divided into 5 categories: North, South, Center, Jerusalem and Judea-Samaria (the West Bank).

National priority relates to incentives from central government sources to encourage development, based on the government index of national priority areas. According to Thompson (1992: p. 45), municipalities seek alternative ways to increase their incomes, aside from raising taxes. That is why the research assumption is that municipalities that are included in national priority areas will be attracted to the private sector and as a result the scope of partnership in these municipalities will be higher than in municipalities not located in national priority areas. The variable national priority was defined nominally as the geographic location of the municipality. The data source is the Ministry of Industry, Trade and Labor, which publishes an index dividing the municipalities into three categories: municipalities in national priority areas A and B, which receive government incentives, and area $\mathrm{C}$, which does not.

Municipality size. Large municipalities have a natural business environment and human resources including available professional, educated and quality manpower, which is vital for economy activities. They also have greater autonomy in management (they need less government approval) and business competition ability. All these are natural economic incentives for entrepreneurs and enable these municipalities to create more partnerships than small cities. The variable municipality size indicates the number of its residents. The data are from CBS. There are two categories: 1) small municipalities with up to 16,000 residents and 2) large municipalities with more than 16,000 residents. The assumption is that the SOP in large municipalities will be bigger than in small ones.

Development policy relates to the incentives (reductions, concessions, discounts/exemptions from taxes, either permanent or temporary, allocation of land, or change of land-use designation) determined by the municipality to encourage entrepreneurs from the private and voluntary sectors. The purpose was to examine which incentives are included in the 'incentives basket' of most local municipalities and whether there is a typical "in- 
centives basket". The choice of the variable development policy is based on the assumption that in the local municipalities that have a development policy (which includes an "incentives basket"), the SOP will be larger than in local municipalities that have no such policy. This variable was measured by the following item: "Does the local municipality use an "incentives basket"? If not, why not? If yes, which incentives are included?" The answer to the open-ended question, "Why not?" was coded into 5 nominal categories.

Municipal scope of partnership (SOP) - the dependent variable, was defined here as the degree of business partnership between the local municipality and the private/voluntary sector. It refers to all economic partnerships between the local municipality and its corporation companies with private and voluntary sectors or with non-governmental bodies. The partnership shares the risks, ownership, management, distribution, funding and incomes (not necessarily all together or in this order). The term "business partnership" was chosen because it implies the participation of private capital in public development, based on shared interests and risks. The most common partnerships are through an urban company or a subsidiary company of the local municipality in partnership with the private sector. Some of the partnerships are with the voluntary sector, giving concessions to build a facility or a service provision franchise. Another partnership method is BOT (build, operate and transfer). The variable is divided into two categories: small-a municipality with $1-2$ partnerships, and large - a municipality with 3 or more partnerships.

\subsection{Findings}

In the first stage of the analysis, the correlations between each one of the independent variables and the dependent variable (SOP) were examined using cross-tabulation analysis and a chi-square test. In the second analysis, the research model and the central hypotheses were examined using OLS regression.

Table 1 indicates that there is a statistically significant correlation $(\mathrm{r}=0.62, p=0.0001)$ between development policy and the number of partnerships. Municipalities that did not use an "incentives basket" (88\%) were found to have small SOP compared to the $27 \%$ of municipalities that used an "incentive basket". Of the municipalities that did use the "incentive basket", $73 \%$ had large SOP compared to only $12 \%$ that did not use the "incentive basket". This suggests that the use of the 'incentive basket' leads to larger SOP in the local municipality. There is also a strong statistically significant correlation $(\mathrm{r}=0.46, p=0.007)$ between municipal population characteristics and SOP: $89 \%$ of the weak municipalities $(1-5)$ had low SOP, while $53 \%$ of the strong municipalities (6 - 10) had high SOP. For all other independent variables: municipality head characteristics $(\mathrm{r}=0.14, p$

Table 1. Correlations between independent variables and SOP (Chi-square test).

\begin{tabular}{|c|c|c|c|c|c|c|}
\hline \multirow{2}{*}{\multicolumn{2}{|c|}{ Independent variables }} & \multicolumn{2}{|c|}{ Partnerships $^{\mathrm{a}}$} & \multirow{2}{*}{$p$} & \multirow{2}{*}{ D.F. } & \multirow{2}{*}{$\mathrm{Chi}^{2}$} \\
\hline & & Few $(1-2)$ & Many (3+) & & & \\
\hline \multirow{2}{*}{ Development policy } & Not used & $88 \%$ & $12 \%$ & 0.001 & 1 & $10.8 \mathrm{~N}=28$ \\
\hline & Used & $27 \%$ & $73 \%$ & & & \\
\hline \multirow{2}{*}{$\begin{array}{c}\text { Municipal } \\
\text { characteristics }\end{array}$} & Weak $(1-5)$ & $89 \%$ & $11 \%$ & 0.001 & 1 & $6.9 \mathrm{~N}=33$ \\
\hline & Strong $(6-10)$ & $47 \%$ & $53 \%$ & & & \\
\hline \multirow{2}{*}{$\begin{array}{l}\text { Municipal head } \\
\text { characteristics }\end{array}$} & Weak & $67 \%$ & $33 \%$ & 0.42 & 1 & $0.64 \mathrm{~N}=33$ \\
\hline & Strong & $83 \%$ & $17 \%$ & & & \\
\hline \multirow{2}{*}{ Municipal size } & Small (up to16,000) & $82 \%$ & $18 \%$ & 0.25 & 1 & $1.3 \mathrm{~N}=32$ \\
\hline & Large (over 16,000) & $62 \%$ & $38 \%$ & & & \\
\hline \multirow{2}{*}{ National priority } & Gets incentives & $67 \%$ & $33 \%$ & 0.73 & 1 & $0.12 \mathrm{~N}=33$ \\
\hline & Gets no incentives & $72 \%$ & $28 \%$ & & & \\
\hline \multirow{5}{*}{ Geographic location } & North & $69 \%$ & $31 \%$ & 0.69 & 4 & $2.2 \mathrm{~N}=33$ \\
\hline & South & $83 \%$ & $17 \%$ & & & \\
\hline & Center & $60 \%$ & $40 \%$ & & & \\
\hline & Jerusalem & $100 \%$ & $0 \%$ & & & \\
\hline & Judea-Samaria & $50 \%$ & $50 \%$ & & & \\
\hline
\end{tabular}

${ }^{\mathrm{a}}$ In this analysis, SOP was measured on a ratio scale and coded into a dichotomous variable. 
Table 2. Contribution of independent variables to SOP (multiple regression).

\begin{tabular}{cccc}
\hline Independent variables & $\boldsymbol{p}$ & $\boldsymbol{\beta}$ & B \\
\hline Development policy & 0.001 & 0.623 & 0.613 \\
Municipal characteristics & 0.044 & 0.376 & 0.363 \\
Municipal head characteristics & 0.553 & 0.092 & 0.125 \\
Municipality size & 0.583 & 0.106 & 0.112 \\
Geographic location & 0.098 & 0.296 & 0.115 \\
National priority & 0.114 & 0.323 & 0.026 \\
Constant & 0.253 & - & 0.625 \\
N & 27 & & \\
\hline
\end{tabular}

$\mathrm{R}^{2}=0.59 ;$ Adj $\mathrm{R}^{2}=0,47 ; \mathrm{Sig}=0.004 ; \mathrm{N}=27$.

$=0.43)$, municipality size $(\mathrm{r}=0.2, p=0.26)$, geographic location $(\mathrm{r}=0.04, p=0.73)$ and national priority $(\mathrm{r}=$ $0.06, p=0.73$ ), no significant correlation with SOP was found.

Table 2 presents the results of a multiple regression analysis to explain the level of SOP in the municipalities. The findings indicate that the development policy of the municipality and municipal population characteristics have significant positive influence on SOP. Development policy has the strongest influence on SOP $(\beta=0.623)$ while municipal population characteristics have a significant but weaker influence $(\beta=0.376)$. In other words, the influence of development policy on SOP found expression in the transition from the lack of a development policy to a development policy situation (implementation of development policy or the existence of the transition), which increased the SOP in the municipality by 0.6 units. The influence of municipal characteristics on SOP found expression in the transition from a weak municipal status $(1-5)$ to a strong municipal status $(6-10)$, which increased the SOP by 0.37 (standard units).

\section{Discussion}

The findings indicate that most of the local municipalities (60\%) have business partnerships and more than a third (39\%) have more than one business partnership. Of the $40 \%$ of municipalities that have no business partnerships, the reason seems to be the lack of opportunity to create partnerships, mainly because of economic weakness. The most common partnership type is a contractual engagement (26\%), and $21 \%$ of the partnerships are through municipal companies.

The findings show that the most frequently found partnerships are in the area of water and sewage, with $87 \%$ of the municipalities having one partnership in this area. The explanation for this is the central government's decision to encourage the establishment of water and sewage corporations. In second place were partnerships in real estate $(19 \%)$. Indeed, $62 \%$ of the partnerships with the private sector related to the construction of a shopping or commercial center. While most partnerships in real estate are with the private sector because these involve large financial investments, partnerships in the education and welfare area are mainly with the voluntary sector and usually involve government funds and grants.

Other findings show high satisfaction (in 97\% of municipalities) with their partnership arrangements because of their influence on the local economy. More than $50 \%$ of the municipalities indicate no use of development policy ("incentives basket") to encourage partnerships and mention the lack of legality of the incentives. In spite of this, $35 \%$ of the municipalities use development policy, some with permits from the Ministry of the Interior and others that break the law by doing so. Unfortunately, control of the Ministry of the Interior is weak (Alterman, 1999; Applebaum \& Hazan, 2005; Ben-Elia, 1999; Razin, 2002; Razin \& Hazan, 2006) and some local municipalities take advantage of this. For example, the most common incentive (in $48 \%$ of municipalities) concerns property tax reductions. Because this is part of municipal self-income, the central government has difficulty preventing incentives in this area. Finally, we see that strong municipalities $(6-10)$ had 4.5 times the number of partnership than weak municipalities $(1-5)$. The other variables: geographic location, national priority, municipality head characteristics and municipality size, had no influence on the SOP. To sum up, the findings clearly show that strong municipalities, from a socio-economic point of view that use incentives in their development policy can influence their SOP. Large local municipalities can choose to create or not to create 
business partnerships.

The research findings show that the most common partnership types are contractual engagement and municipal companies. Municipal characteristics and development policy (incentives basket) have a significant influence on SOP and are dominant variables in attracting financial entrepreneurship, which affects the municipal economy. The characteristics of the head of the municipality have no significant influence on SOP, nor do geographical location, but the general direction of their influence is positive and corresponds to the research assumption. Satisfaction of the local municipalities with the partnerships is high because they enable them to carry out projects quickly and efficiently, which contributes to the attractiveness of the municipality, enables the municipalities to improve their financial balance sheet and the quality of welfare services to its residents.

Approximately half of the municipal companies in Israel undertake urban development (urban infrastructure, attraction of entrepreneurs and the creation of places of employment) and the remainder deal with the delivery of public services and management of public assets. The goals are efficiency and improvement of service delivery, reduction of costs, and an increase the municipal profits. Another contribution of the municipal companies is the ability to bypass bureaucracy while continuing to control the service. Indeed, the most widespread use of municipal companies is to purchase land or assets, and to undertake projects that the municipality would otherwise be prevented from performing.

\section{Summary and Conclusion}

Municipal partnerships increase the attractiveness and image of the local municipalities. The change in the central government's development policy and the reduction of finance from this source augment the significance and the contribution of the partnership to municipal performance and economic development. The use of development policy (incentives) in spite of the prohibition by the Ministry of the Interior explains and emphasizes the importance of partnerships to municipal economic development. The partnership with the private and voluntary sectors enables the local municipalities to cooperate with bodies outside of government and to involve groups of citizens in the decision-making process, which strengthens the local democracy. At the same time, the partnership emphasizes the equity resource distribution and lack of economic equality among municipalities because of the differences in their ability to attract economic entrepreneurship.

Behavioral patterns were distinguished which were highly influenced by the complicated relationship between the central government and the local municipalities. Israel is a state characterized by high centralization, whose cores are the regulations, orders and statutes that create the supervisory and control policy of the Ministry of Interior and the Treasury towards local municipalities. The creative solution used by most local municipalities is the creation of municipal companies, through which the municipality can engage in business activity otherwise making it difficult or impossible because of central government restrictions. Actually, the municipal company serves as a managerial tool for service delivery in an economic manner under public direction. Razin (2003), who has studied the local government system in Israel from an international comparative perspective, explains that the difference in the functioning of Israel's local municipalities from those in other developing countries is in the considerable gap between formal local government frameworks and behavior patterns in practice. In Israel, behavior patterns have changed considerably, yet the formal-administrative establishment has not sufficiently adapted to the new conditions (Razin, 2003: p. 9). In other words, the dynamics of reform in Israel are completely different from those in other emerging countries.

The results of this research also indicate a behavioral shift from privatization in public service delivery and management to mixed public-private delivery (joint contracting) of city services among city managers in Israel as found in Europe and the US. The large number of municipal companies indicates the general tendency of municipality involvement and reflects the high dependence of the municipalities on central government funds and approval (Hasson, 1996: p. 52).

However, from the initial data collected for the present research, it is clear that there are conflicting trends. On one hand, there is a strong tendency to continue centralized government control (administration, supervision, guidance and government funding), while, on the other hand, there is a significant tendency to decentralization, the desire to delegate authority and functions to non-governmental bodies. In other words, although the Israeli government is not keen to relinquish authority (even when partnership with the business sector is useful), the government imposes the responsibility of essential services on non-governmental organizations.

This matter has raised questions concerning the true intention underlying the government's actions. Does the 
government's tendency to transfer certain functions to non-governmental organizations and thus to relinquish a source of power reflect an honest desire to design a "mixed economy" system, or does it express an aspiration to fulfill a central role, while using methods which better suit the current climate? Razin (2003) believes that the government transfers the difficult and complex job of delivering certain services to other organizations, but ensures that it retains full responsibility for the funding of these services and their supervision, and thus, in fact, continues to control the services. In his opinion, the trend of government policy inclines in the direction of renewed centralization in the name of effectiveness, using partnership and privatization, which largely bypasses the local municipalities that have failed.

With regard to the processes taking place in Israel, it can be concluded that the trend towards partnership between the public sector and the private sector will continue to strengthen. As the financial resources available to the local municipalities diminish, they will be forced to find alternative methods of delivering services at lower cost, in order to ensure that municipal expenses do not exceed their incomes. The local municipality must be more ready than ever to integrate very limited public resources with private resources, in order to meet the community's needs, and for this purpose it will need the participation of non-governmental organizations in its activities. Therefore, it seems likely that local municipalities will increasingly provide services through bodies outside the local municipality.

\section{References}

Alterman, R. (1999). Between Privatization and Continued National Ownership: A Future Land Policy for Israel. Jerusalem: Floersheimer Institute for Policy Studies. (In Hebrew)

Applebaum, L., \& Hazan, A. (2005). Cooperation between Small Municipalities: Lessons for Israel. Jerusalem: Floersheimer Institute for Policy Studies. (In Hebrew)

Ben-Elia, N. (1996). Organizational Reorientation and Learning in Israeli Local Government: The Role of Market Type Mechanisms. In N. Ben-Elia (Ed.), Strategic Changes and Organizational Reorientations in Local Government: A Cross National Perspective (pp. 1-19). London: Macmillan.

Ben-Elia, N. (1999). Government Finance and the Fiscal Crisis in Israeli Local Authorities. Jerusalem: The Floersheimer Institute for Policy Studies. (In Hebrew)

Carmeli, A. (2000). The Relation between Organizational Resources and Performance-Failure and Success-of Local Authorities in Israel. Unpublished Doctoral Dissertation, Haifa: University of Haifa. (In Hebrew)

de Socio, M. (2007). Business Community Structures and Urban Regimes: A Comparative Analysis. Journal of Urban Affairs, 29, 339-366. http://dx.doi.org/10.1111/j.1467-9906.2007.00350.x

DiGaetano, A., \& Strom, E. (2003). Comparative Urban Governance: An Integrated Approach. Urban Affairs Review, 38, 356-395. http://dx.doi.org/10.1177/1078087402238806

Dowding, K. (2001). Explaining Urban Regimes. International Journal of Urban and Regional Research, 25, 7-19. http://dx.doi.org/10.1111/1468-2427.00294

Dye, T. R., \& Garcia, J. A. (1978). Structure, Function, and Policy in American Cities. Urban Affairs Quarterly, 14, 103123. http://dx.doi.org/10.1177/107808747801400105

Elkin, S. L. (1987). City and Regime in the American Republic. Chicago, IL: University of Chicago Press.

Frisby, W., Thibault, L., \& Kikulis, L. (2004). The Organizational Dynamics of Under-Managed Partnerships in Leisure Service Departments. Leisure Studies, 23, 109-126. http://dx.doi.org/10.1080/0261436042000224482

Hanley, B. (2003). The Good, the Bad, and the Ugly: Arts Partnerships in Canadian Elementary Schools. Arts Education Policy Review, 104, 11-20. http://dx.doi.org/10.1080/10632910309600975

Hasson, S. (1996). The New Urban Order: Urban Coalitions in Israel. Jerusalem: The Floersheimer Institute for Policy Studies. (In Hebrew)

Hasson, S., \& Hazan, A. (1997). Municipal-Private Partnership: Opportunities and Risks. Jerusalem: The Floersheimer Institute for Policy Studies. (In Hebrew)

Hebdon, R., \& Jalette, P. (2008). The Restructuring of Municipal Services: A Canada-United States Comparison. Government and Policy, 26, 144-158. http://dx.doi.org/10.1068/c0634

Hefetz, A., \& Warner, M. (2007). Beyond the Market versus Planning Dichotomy: Understanding Privatization and Its Reverse in US Cities. Local Government Studies, 33, 555-572. http://dx.doi.org/10.1080/03003930701417585

Hurte, S. M. (2004). Profit at the Expense of Compliance? Assessing the Impact of Ownership Type on Compliance with the Safe Drinking Water Act. Proceedings of the Annual Meeting of the Midwest Political Science Association, Chicago, 15- 
18 April 2004. http://www.allacademic.com/meta/p83771 index.html

Katan, J. (2001). Implementation of a Privatization Policy in the Long-Term Care Community Services: Preliminary Conclusions. Social Security, 60, 129-155. (In Hebrew)

Katan, J. (2004). Local Social Services: An Arena Crowded with Organizations. In Y. Kop (Ed.), Resource Allocation for the Social Services (pp. 171-190). Jerusalem: Taub Center for Social Policy Studies in Israel. (In Hebrew)

Kidd, D. (2002). Battle Lines at Toronto City Hall. Canadian Dimension, 36, 12.

Kop, Y. (2004). Government Expenses for Social Services. In Y. Kop (Ed.), Resource Allocation for the Social Services (pp. 71). Jerusalem: Taub Center for Social Policy Studies in Israel. (In Hebrew)

Kuhlmann, S. (2008). Reforming Local Public Services: Trends and Effects in Germany and France. Public Management Review, 10, 573-596. http://dx.doi.org/10.1080/14719030802264234

Lake, R. W. (2002). Bring Back Big Government. International Journal of Urban and Regional Research, $26,815-822$. http://dx.doi.org/10.1111/1468-2427.00420

Lamothe, S., Lamothe, M., \& Feiock, R. C. (2008). Examining Local Government Service Delivery Arrangements over Time. Urban Affairs Review, 44, 27-56. http://dx.doi.org/10.1177/1078087408315801

Lev-Ari, L., \& Pavin, A. (2006). Social Capital as a Stimulus to Development in the Periphery. Horizons in Geography, 6 , 95-113. (In Hebrew)

Ohemeng, F. K., \& Grant, J. K. (2008). When Markets Fail to Deliver: An Examination of the Privatization and De-Privatization of Water and Wastewater Services Delivery in Hamilton, Canada. Canadian Public Administration, 51, 475-499. http://dx.doi.org/10.1111/j.1754-7121.2008.00034.x

Razin, E. (2002). Fiscal Disparities among Local Authorities in Israel in the Year 2000: Continuity and Change in a Period of Political Instability. Jerusalem: The Floersheimer Institute for Policy Studies. (In Hebrew)

Razin, E. (2003). Local Government Reform in Israel: Between Centralization and Decentralization, between Traditionalism and Modernity. Jerusalem: The Floersheimer Institute for Policy Studies. (In Hebrew)

Razin, E., \& Hazan, A. (2006). Redistributing Municipal Revenues: Fiscal Measures and Territorial Changes. Jerusalem: The Floersheimer Institute for Policy Studies. (In Hebrew)

Reese, L. A., \& Rosenfeld, R. A. (2002). Reconsidering Private Sector Power: Business Input and Local Development Policy. Urban Affairs Review, 37, 642-674. http://dx.doi.org/10.1177/107808740203700502

Schmid, H. (2001). Nonprofit Organizations and For-Profit Organizations Providing Home Care Services to the Israeli Frail Elderly: A Comparative analysis. International Journal of Public Administration, 24, 1223-1265. http://dx.doi.org/10.1081/PAD-100105237

Schwarz, R. (2003). Managing the Connection between Local Municipalities and Non-Profit Organizations. Jerusalem: JDC-ELKA. (In Hebrew)

Silver, I. (2001). Poverty Reform through Philanthropic Initiative. Society, 38, 28-32. http://dx.doi.org/10.1007/s12115-001-1037-2

Stein, R. M. (1990). Urban Alternatives: Public and Private Markets in the Provision of Local Services. Pittsburgh, PA: University of Pittsburgh Press.

Stone, C. N. (1980). Systemic Power and Community Decision Making: A Restatement of Stratification Theory. American Political Science Review, 74, 978-990. http://dx.doi.org/10.2307/1954317

Stone, C. N. (2005). Looking Back to Look Forward: Reflections on Urban Regime Analysis. Urban Affairs Review, 40, 309-341. http://dx.doi.org/10.1177/1078087404270646

Thompson, S. (1992). Privatization-Possibly Positive Politics. American City \& County, 107, 45-47.

Warner, M. E. (2006). Market-Based Governance and the Challenge for Rural Governments: US Trends. Social Policy \& Administration, 40, 612-631. http://dx.doi.org/10.1111/j.1467-9515.2006.00523.x

Warner, M. E. (2009). Civic Government or Market-Based Governance? The Limits of Privatization for Rural Local Governments. Agriculture and Human Values, 26, 133-143. http://dx.doi.org/10.1007/s10460-008-9181-6

Warner, M. E., \& Bel, G. (2008). Competition or Monopoly? Comparing Privatization of Local Public Services in the US and Spain. Public Administration Quarterly, 86, 723-735. http://dx.doi.org/10.1111/j.1467-9299.2008.00700.x

Warner, M. E., \& Hebdon, R. (2001). Local Government Restructuring: Privatization and Its Alternatives. Journal of Policy Analysis and Management, 20, 315-336. http://dx.doi.org/10.1002/pam.2027

Warner, M. E., \& Hefetz, A. (2008). Managing Markets for Public Service: The Role of Mixed Public-Private Delivery of City Services. Public Administration Review, 68, 155-166. http://dx.doi.org/10.1111/j.1540-6210.2007.00845.x 


\section{Appendix}

\section{Questionnaire}

\section{Definition of business partnership}

Business partnerships between local municipalities and the private sector enable the local municipality to improve the urban economy. Business partnerships consist of collective ownerships and joint management, characterized by one or more of the following: assigning of concessions; combined transactions; joint projects with collective ownership or joint management; creating projects with shared income. The partnership is based on shared incomes, with a sharing of responsibility and risks at all stages of the planning, finance, construction and implementation.

1. Does your local municipality operate such partnerships? $\quad$ Yes $\square \quad$ No $\square$

2. Does your local municipality currently have any active partnerships? Yes $\square \quad$ No $\square$

3. If yes, how many active private sector partnerships are there?

4. If no, that is, your local municipality does not operate any private sector partnerships, please explain why.

5. If your local municipality has partnerships with the private sector, please specify how many according to type of organizational structure:

Number of

a. Contractual arrangements

b. Municipal companies (urban company or a subsidiary company of the local municipality)

c. BOT (Build, Operate and Transfer)

d. Subsidiary companies

Total

The area of your local municipalities partnerships

6. Please indicate the number of partnerships your local municipality has in each of the following areas:
a. Hi-tech
b. Real estate
c. Water and sewage
d. Infrastructure: roads, streets, lights
e. Construction
f. Industrial/commercial
g. Tourism
h. Education service, welfare, society, culture and sport
i. Others, please specify

Total

\section{Organizations in the partnership}

7. Of all business partnerships in your local municipality, how many partnerships are with the:
a. Government?
b. Private sector?
c. c. Voluntary bodies?

Total

\section{Satisfaction}

8. In general, what is the level of your local municipality's satisfaction with the partnership arrangements?
5. Very satisfied $\square$
4. Satisfied $\square \quad$ 3. Not satisfied $\square$
2. Not at all satisfied $\square$
1. Don't know $\square$

9. Of all the partnerships operated by your local municipality, how many are intended to achieve these goals?

Goals

a. Improve balance of accounts

b. Improve service quality

\section{Number of partnerships}


c. Develop economic activities

d. Improve citizens' welfare

e. Reinforce the political status of the head of the municipality

f. Increase the attractiveness of the local municipality

g. All of the above

h. Other goals, please specify

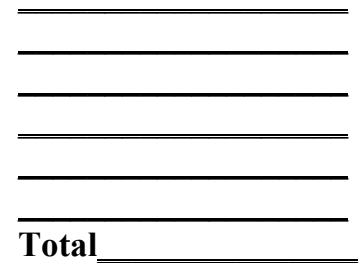

10. In general, how do the business partnerships affect your local municipality's activities?
a. Negative effects $\square$

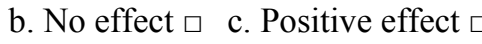
d. Don't know $\square$

11. Of all your local municipality's business partnerships, how many contributed to these goals?

Main contribution

a. Increasing income of local municipality

b. Improvement in service quality

c. Both of the above

d. Developing economic activities

e. Improvement in welfare of citizens

f. Reinforcing political status of municipality leaders

g. Increasing attractiveness of local municipality

h. Performance improvement

i. Reduction in bureaucracy

j. All of the above
Number of partnerships

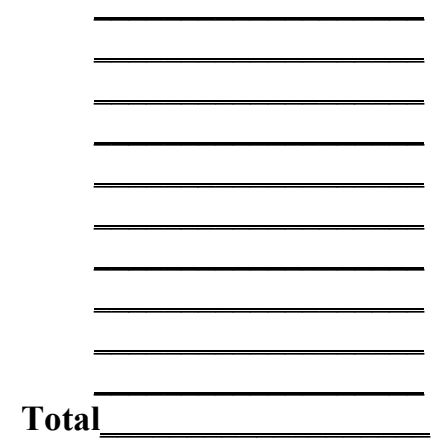

\section{Local municipality incentives (incentives basket)}

12. Does the local municipality currently use an incentives basket in order to promote creation of partnerships with the business sector?
a. Yes.
b. No.
c. Don't know $\square$

13. If your local municipality doesn't use an incentives basket, please specify the reason:

14. Indicate which incentives are included in your local municipality's incentives basket:

(Please indicate more than one if relevant)
a. Development tax flexibility
included/not included
b. Payment restructuring
c. Tax reduction
d. Temporary tax exemption included/not included included/not included included/not included
e. Change of land use included/not included
f. Support/participation in infrastructure development included/not included g. Other incentives

15. Of all your current local municipality business partnerships please indicate how many of them use the following incentives:

Incentives

a. Development tax flexibility

b. Payment restructuring

c. Tax reduction

d. Temporary tax exemption

e. Change of land use

f. Infrastructure development

g. Other incentives

\section{Number of partnerships}

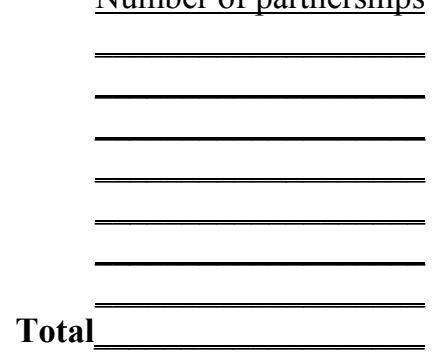

\section{Respondent's background}

16. What is your role in local government?

a. Elected Mayor 
b. General Manager of the municipality

c. Finance Director

d. C.E.O of the municipal company

e. Other

17. What is your professional background?
a. Business background
b. Public/civil background
c. Defense forces background
d. Other, please specify:

18. Please elaborate on your professional background. Which positions did you hold previously?

19. Consider the business partnership operating in your local municipality today. How many were you involved in creating and/or are you involved in operating?

20. In your view, how many business partnership between your local municipality and the business sector are planned or will be formed or created in the next two years?

\section{Characteristics of elected mayor and governing coalition}

21. Number of periods governed

22. Number of mandates currently held in the coalition

23. Please assess the stability of your municipality's governing coalition:
a. Stable $\square$
b. Unstable $\square$
c. Don't know or other $\square$ 